\title{
Investigation of the outcome of patients with hip fractures using vitamin D3
}

\author{
Ahmadreza Behrouzi (1), Hojat Hejazi (1), Alireza Kamali (2), Hoseinali Hadi (1) \\ (1) Department of Orthopedics, Arak University of Medical Sciences, Arak; (2) Department of \\ Anesthesiology, Arak University of Medical Sciences, Arak Iran
}

This article is distributed under the terms of the Creative Commons Attribution Noncommercial License (CC BY-NC 4.0) which permits any noncommercial use, distribution, and reproduction in any medium, provided the original author(s) and source are credited.

\begin{abstract}
Hip fracture is one of the important health problems of human societies. The aim of this study was to investigate the outcome of patients with this fracture using vitamin D3. This double-blind clinical trial was performed on 100 patients with hip fractures who referred to Valiasr Hospital. All specimens were evaluated for vitamin D3. Group A have had vitamin D3 in the normal range and received a dose of 50,000 vitamin D3 as blouse. Group B included individuals with hip fractures that did not have normal vitamin D3 levels. In this group, individuals received a dose of 50,000 units vitamin D3 in the form of muscular blouse, and then 50,000 units of vitamin D3 were given orally each week up to 12 weeks after surgery. After surgery, both groups were examined clinically and radiologically for ulcer and fracture healing. Moreover, mortality was checked 2 weeks after surgery and each month until healing. There was no significant difference in radiographic examination in the two groups in the term of adhesion and fracture union ( $\mathrm{P}$ $<0.05)$. The formation of the union in the clinical examination 4 and 8 weeks after treatment in two groups showed significant difference. The formation of union in clinical presentation 4 weeks and 8 weeks after treatment in two groups showed significant difference $(\mathrm{P}=0.005 ; \mathrm{P}=$ 0.036). The results showed that a group with low vitamin $D$, but with supplementation, had more fracture union after 4 and 8 weeks after starting treatment. Vitamin D supplementation could improve patients' condition 4 and 8 weeks after treatment.
\end{abstract}

Key Words: Hip fracture, Vitamin D3, outcome of the disease.

Eur J Transl Myol 28 (3): 288-293, 2018

Hip fracture is one of the important health problems. ${ }^{1}$ The annual incidence of these fractures in the United States increased from 250,000 in 1995 to 340,000 in 2005 , and is expected to reach about 500,000 in $2040 .^{2}$ These fractures do not have good prognosis and one third of old patients die within one year of this fracture. ${ }^{3,4}$ Only about $30-40 \%$ of patients with fractures around the hip joint recover their preoperative life-style behaviors. ${ }^{5}$ It is worth noting that more than $50 \%$ of these patients experience permanent disability, immobility and assistance in their daily activities. This greatly reduces the quality of life and their health. ${ }^{3,5,6}$ Osteoporosis is the main cause of hip fractures in people over the age of 65 years and $90 \%$ of these fractures occur in people aged 65 and older. ${ }^{7}$. Based on litterature, the main factors involved are age, bone mass loss, falls, cigarette, diabetes, low level of health, immobility, low body weight, lack of exercise, history of fracture after age 50 and maternal history of neck or hip fractures. Although hip fracture is a global health problem, there are significant differences in prevalence and its risk factors in different geographical areas and among different ethnic groups. On the other hand, most of the available data about this common problem and its risk factors is related to the Western countries, which is influenced by the cultural context, population distribution, and the pattern of nutrition and activity affects the incidence of this disease. In this regard, in Iran and other Muslim countries there are significant differences with the Eastern societies. A recent study in Jordan shows that there is a high prevalence of these fractures in Jordanian women, that occurred at lower ages compared with western countries. ${ }^{9}$ The incidence of hip fracture in our patients is about 14 years younger than in advanced countries, where the proportion of women with hip fractures is more than in the men. ${ }^{10}$ About one billion people worldwide have vitamin D deficiency. ${ }^{11}$ Vitamin $\mathrm{D}$ deficiency reduces muscle endurance and increases the 


\section{Vitamin D3 in hip fractures}

Eur J Transl Myol 28 (3): 288-293, 2018

risk of fracture due to defects in skeletal mineralization. ${ }^{12,13}$ Low levels of vitamin $\mathrm{D}$ are associated with poor absorption of calcium in the serum, leading to bone mass loss. ${ }^{14}$. Paul and colleagues also reported in 2015 that vitamin D deficiency was more common in people with femoral neck fractures than in healthy subjects. ${ }^{15}$ Falcker et al in 2016 indicated that $78 \%$ of the patients with hip fractures suffered from vitamin D deficiency, suggesting that mortality in people with moderate and severe vitamin D deficiency would increase. ${ }^{16}$ Treatment of osteoporotic fractures and especially hip fractures is shown to be much more difficult than its prevention. Therefore, the present study was aimed to investigate the outcome of patients with hip fractures using vitamin D3.

\section{Materials and Methods}

This double-blind clinical trial was conducted, in patients with hip fracture referred to Valiasr Hospital, after obtaining personal consent. They were enrolled according to the following inclusion and exclusion criteria. One hundred patients were selected among those suffering with intertrochanteric fracture. All subjects were evaluated for vitamin D3 and patients were finally divided into two groups: Fifty patients with elevated levels of vitamin D (Group A) and fifty patients with low levels of vitamin D (Group B). Group A had a natural

Table 1. shows the mean and standard deviation of age in both groups with normal vitamin D and low vitamin D.

\begin{tabular}{|r|r|r|r|}
\hline Variables groups & Vitamin D & Vitamin D & $p$-value \\
Normal & Mean \pm SD & Mean \pm SD & \\
\hline age & & & \\
\hline
\end{tabular}

Table 2. Frequency of sex in two groups with normal vitamin $D$ and low vitamin $D$

\begin{tabular}{|r|r|r|r|r|}
\hline \multicolumn{2}{|l|}{ Variables groups } & $\begin{array}{r}\text { Vitamin D } \\
\text { Normal } \\
\text { Number \% }\end{array}$ & $\begin{array}{r}\text { Vitamin D } \\
\text { Low } \\
\text { Number \% }\end{array}$ & -value \\
\hline \multirow{2}{*}{ Sex } & Women & $(60) 30$ & $(44) 22$ & $0 / 080$ \\
& Man & $(40) 20$ & $(56) 28$ & \\
\cline { 2 - 4 } & & & & \\
\end{tabular}

Table 3. Frequency of adhesion in patients in two groups of normal vitamin $D$ and low vitamin $D$

\begin{tabular}{|c|c|c|c|c|}
\hline \multicolumn{2}{|l|}{ Variables groups } & $\begin{array}{r}\text { Vitamin D } \\
\text { Normal } \\
\text { Number \% }\end{array}$ & $\begin{array}{r}\text { Vitamin D } \\
\text { Low } \\
\text { Number \% }\end{array}$ & p-value \\
\hline \multirow[t]{2}{*}{ Adhesion 2 weeks after treatment } & yes & $(74) 37$ & $(84) 42$ & \multirow[t]{2}{*}{$0 / 163$} \\
\hline & no & $(26) 13$ & $(16) 8$ & \\
\hline \multirow[t]{2}{*}{ Adhesion 4weeks after treatment } & yes & $(86) 43$ & $(92) 46$ & \multirow[t]{2}{*}{$0 / 262$} \\
\hline & no & $(14) 7$ & $(8) 4$ & \\
\hline \multirow[t]{2}{*}{ Adhesion 8 weeks after treatment } & yes & $(100) 50$ & $(100) 50$ & \multirow[t]{2}{*}{$>0 / 05$} \\
\hline & no & $(0) 0$ & $(0) 0$ & \\
\hline \multirow{2}{*}{$\begin{array}{r}\text { Adhesion 12weeks after } \\
\text { treatment }\end{array}$} & yes & $(100) 50$ & $(100) 50$ & \multirow[t]{2}{*}{$>0 / 05$} \\
\hline & no & $(0) 0$ & $(0) 0$ & \\
\hline
\end{tabular}


range of vitamin $\mathrm{D}$, where they received a dose of 50,000 units of vitamin D3 as blouse. Patients with Vitamin D3 deficiency (based on normal laboratory range) were included in group B. Individuals of this group also received a dose of 50,000 units of vitamin D3 as blouse, and then the patients in this group received oral pearl of 50,000 IU vitamin D3 every 12 weeks after surgery. In both groups, bolus doses of vitamin D3 were intramuscularly injected 48 hours before surgery, while in the second group 5000 units of vitamin D3 were given weekly up to 12 th week. After surgery, both groups were evaluated for wound healing, and for improvement of the fracture site by clinical and radiologic evaluations. Clinical improvement with regard to secretion and adhesion strength of the wound site was also investigated. Clinical and radiological fractures have been considered as a benchmark for improvement, if they were clinically painless before and after body weight bearing. Regarding the radiological evaluation, the loss of bone length and Callus formation were taken in to consideration as benchmarks for improvement. From second week after operation, a monthly radiography follow up was carried out and continued until bone welding. Determination of mortality was performed 6 months after fracture surgery. The outcome of the two groups was evaluated. In a double-blind study, the data were collected by an expert assistant, who was unaware of the groupings. Data were analyzed by SPSS-20 using descriptive and analytical statistics. Inclusion criteria: 1. Low energy trauma (e.g., falling); 2. Referral to Valiasr Hospital; 3. Age over 60. Exclusion criteria: (1) lack of patient follow-up; 2. Deaths. All the ethical statements of

Table 4. Frequency of fracture union in radiography of patients in the two groups

\begin{tabular}{|c|c|c|c|c|}
\hline Variables groups & & \multirow{2}{*}{$\begin{array}{l}\text { Vitamin D } \\
\text { Normal } \\
\text { Number \% } \\
(0) 0\end{array}$} & \multirow{2}{*}{$\begin{array}{l}\begin{array}{c}\text { Vitamin D } \\
\text { Low }\end{array} \\
\text { Number \% } \\
(0) 0\end{array}$} & \multirow{3}{*}{$\begin{array}{l}p \text {-value } \\
>0 / 05\end{array}$} \\
\hline \multirow{2}{*}{$\begin{array}{l}\text { Formation of the union in } \\
\text { radiography } 2 \text { weeks after } \\
\text { treatment }\end{array}$} & yes & & & \\
\hline & no & 50 & 50 & \\
\hline \multirow{2}{*}{$\begin{array}{l}\begin{array}{l}\text { Formation of the union in } \\
\text { radiography4 }\end{array} \\
\text { weeks after } \\
\text { treatment }\end{array}$} & yes & $(0) 0$ & $(0) 0$ & \multirow[t]{2}{*}{$>0 / 05$} \\
\hline & no & 50 & 50 & \\
\hline \multirow{2}{*}{$\begin{array}{l}\begin{array}{l}\text { Formation of the union in } \\
\text { radiography } 8 \begin{array}{r}\text { weeks after } \\
\text { treatment }\end{array}\end{array} \\
\end{array}$} & yes & 50 & 50 & \multirow[t]{2}{*}{$>0 / 05$} \\
\hline & no & $(0) 0$ & $(0) 0$ & \\
\hline \multirow{2}{*}{$\begin{array}{l}\text { Formation of the union in } \\
\text { radiography } 12 \text { weeks after } \\
\text { treatment }\end{array}$} & yes & 50 & 50 & \multirow[t]{2}{*}{$>0 / 05$} \\
\hline & no & $(0) 0$ & $(0) 0$ & \\
\hline
\end{tabular}

Table 5. Frequency of fracture union formation in clinical examination in two groups

\begin{tabular}{|c|c|c|c|c|}
\hline \multicolumn{2}{|l|}{ Variables groups } & $\begin{array}{l}\text { Vitamin D } \\
\text { Normal } \\
\quad \text { Number \% }\end{array}$ & $\begin{array}{l}\text { Vitamin D } \\
\text { Low } \\
\text { (Number \% }\end{array}$ & $p$-value \\
\hline \multirow{2}{*}{$\begin{array}{r}\text { Formation of union in a clinical } \\
\text { examination } 2 \text { weeks after } \\
\text { treatment }\end{array}$} & yes & $(0) 0$ & $(0) 0$ & \multirow[t]{2}{*}{$>0 / 05$} \\
\hline & no & $(100) 50$ & $(100) 50$ & \\
\hline \multirow{2}{*}{$\begin{array}{r}\text { Formation of union in a clinical } \\
\text { examination } 4 \text { weeks after } \\
\text { treatment }\end{array}$} & yes & $(70) 35$ & (92)46 & \multirow[t]{2}{*}{$0 / 005$} \\
\hline & no & (30)15 & $(8) 4$ & \\
\hline \multirow{2}{*}{$\begin{array}{r}\text { Formation of union in a clinical } \\
\text { examination } 8 \text { weeks after } \\
\text { treatment }\end{array}$} & yes & $(80) 40$ & (94)47 & \multirow[t]{2}{*}{$0 / 036$} \\
\hline & no & (20)10 & $(6) 3$ & \\
\hline \multirow{2}{*}{$\begin{array}{r}\text { Formation of union in a clinical } \\
\text { examination } 12 \text { weeks after } \\
\text { treatment }\end{array}$} & yes & $(90) 45$ & $(96) 48$ & \multirow[t]{2}{*}{$0 / 218$} \\
\hline & no & $(10) 5$ & (4) 2 & \\
\hline
\end{tabular}


Helsinki and Arak University of Medical Sciences were considered at all stages. This scheme was approved with IR.ARAK.MU.REC.1395.58 Code of Ethics. Code registration in Iran's Clinical Trials Center is: IRCT2016102620258N15.

\section{Results and Discussion}

The minimum age was 62 years and the oldest age was 93 years. The mean age of patients was $75.72 \pm 7.82$ years. Moreover, 52 patients were female, while 48 out of 100 patients were male, without significant difference in terms of age between the two groups Frequency of sex (Table 1). As shown in Table 2 the two groups did not show statistically significant difference in frequency of sex. As to the results, no significant difference was found between the two groups $(\mathrm{P}<0.05)$ and both groups showed adhesion to Vitamin D3 treatment at weeks 8 and 12 (Table 3 and 4). Table 5 shows that there was no significant difference between the two groups in the clinical examination 4 weeks after treatment $(P=0.005)$. On the other hand, fracture union was higher at the clinical examination in the group receiving the supplement with low vitamin D. Fracture union formation in the two groups showed also significant difference in clinical examination 8 weeks after treatment $(P=0.036)$. observing these effects of vitamin D3 supplementation in patients with hip fractures is an important step in improving the patient's well-being. These fractures have no good prognosis and one third of the patients die within one year after the fracture. ${ }^{3,4}$ It is worth noting that only about $30-40 \%$ of patients with hip fractures recover their preoperative motility, ${ }^{5}$ while more than $50 \%$ of these patients experience permanent disability and immobility. Therefore, dietary supplements play a key role in the outcomes of fracture surgery. About one billion people have vitamin D deficiency worldwide. ${ }^{11,17}$ Vitamin D deficiency reduces muscle endurance and subsequently can increase the risk of fracture due to defects in skeletal mineralization. ${ }^{12,13,17,18}$ Low levels of vitamin D are associated with malabsorption of calcium, leading to bone $\operatorname{loss}^{14,19,20}$ Paul et al. also reported in 2015 that vitamin D deficiency was more common in people with hip fractures than healthy people, and recommended extensive screening for these subjects. ${ }^{15}$ Falcker et al. in 2016 demonstrated that $78 \%$ of the patients with hip fractures suffered with vitamin D deficiency, suggesting that mortality in people with moderate and severe vitamin D deficiency would increase. ${ }^{16}$

In the present study, we investigated the effect of vitamin $\mathrm{D}$ on the outcome of hip fractures' surgery. The results indicated that patients receiving supplementation (but with low vitamin D), the formation of the fracture union was greater after 4 and 8 weeks of treatment. Kelsey et al. (2016) investigated the effect of diet and nutritional supplements in recovery from hip fracture in the elderly. ${ }^{21}$ Their study showed that simple nutritional supplements have no significant effect in health outcomes following fracture, while limited nutritional effects have been reported in recovery from hip fracture. Paul et al. evaluated the deficiency of vitamin D and other risk factors related to femoral neck fractures in South Indian postmenopausal women. One hundred four postmenopausal women entered the study with femoral neck fractures that were matched for age and BMI. The rate of sedative use, low FN BMD and vitamin D deficiency $(<20 \mathrm{ng} / \mathrm{ml})$ in femoral neck fractures was higher than the control group $(\mathrm{p} \leq 0.05)$. At the end of the year, $20 \%$ of fractures and $5 \%$ of the control subjects had died $(p=0.001)$. The risk factors studied in this study are of Indian origin and should be investigated in other areas where further studies are recommended..$^{15}$ Our study did not show mortality during the 6-month study. This difference could be due to the duration of the study, since Paul and colleagues conducted a one-year study with higher sample size. Tkatch et al. (2013) examined the role of oral protein supplements in patients with the proximal femur fracture. They randomly divided 62 patients with the proximal femur fracture into two groups. One group received $250 \mathrm{ml} /$ day of oral protein supplement, mineral salts (calcium: $0.525 \mathrm{~g}$ ) and vitamins (A: $750 \mathrm{IU}$ and D3: $25 \mathrm{IU}$ ) for 38 days. The control group received the same supplements except supplemental protein for the same period of time. The clinical course in the protein intake group was considerably better, where recovery was observed in $79 \%$ of patients, compared to $36 \%(\mathrm{P}<0.02)$ in the control group. The rate of complications and deaths was in their 7-month study significantly lower in the protein supplement group than the control group. The median hospitalization in the group receiving the protein supplement was lower than the other group (69 days versus 102 days). ${ }^{22}$ Our results are not consistent with their study, since there was no mortality due to the difference in the duration of supplementation. In our study, the duration of the course was 84 days, while in the mentioned study there was a 38-day follow-up. In 2003 Trivedi et al. reported the effect of four monthly oral vitamin D3 on men and women fractures and mortality. In is worth noting those 2686 males and 649 females aged 65-85 years participated in this study. The relative risks of vitamin $\mathrm{D}$ group compared to placebo group were 0.78 for any first fracture $(\mathrm{P}=0.04)$. Furthermore, 471 people died after 5 years. Relative mortality rate in the vitamin D group was $88 \%$ compared to the placebo group. They concluded that four months of supplementation with $100000 \mathrm{IU}$ oral vitamin D can prevent fractures in the British population. ${ }^{23}$ In the present study, the two groups showed a significant difference in terms of union fracture 4 and 8 weeks after treatment. In the group with low levels of vitamin D supplementation, union fracture was also greater in clinical examinations after 4 and 8 weeks. As to the stumps adhesion, there was no significant difference between the two groups, since in both groups, all patients had adhesion at week 8 and 12. There was also no 
significant difference between the two groups in terms of union of fracture in the 2nd and 4th weeks after treatment. However, at 8 and 12 weeks after treatment, all patients in the two groups had union formation in radiography. In conclusion, the formation of the union in the clinical examination 4 and 8 weeks after treatment in the two groups showed significant difference. In the group with low levels of vitamin $\mathrm{D}$, but with supplement, union fracture was greater in clinical examinations after 4 and 8 weeks. Indeed, it caused painless walking and painless weight bearing in patients.

\section{List of acronyms}

BMI- Body mass index

FN -Femoral neck

BMD- Distal forearm bone mineral density

\section{Author's contributions}

$\mathrm{ARB}, \mathrm{HH}, \mathrm{AK}$, and $\mathrm{HH}$ equally participated in experimental design, data collection, writing and revision of the manuscript.

\section{Acknowledgments}

Funding: None.

\section{Conflict of Interest}

The authors declare no conflicts of interests.

\section{Ethical Publication Statement}

We confirm that we have read the Journal's position on issues involved in ethical publication and affirm that this report is consistent with those guidelines.

\section{Corresponding Author}

Hojat Hejazi, Department of Orthopedics, Arak University of Medical Sciences, Arak, Iran. Phone 00989155122022. Email: hejazi@gmail.com

E-mail of co-authors

AhmadrezaBehrouzi: dr.behrouzi@arakmu.ac.ir

AlirezaKamali:dr.kamali@arakmu.ac.ir

HoseinaliHadi: hosseinali_hadi@yahoo.com

\section{References}

1. Currie C, Hutchison P, Platt H, et al. Prevention and management of hip fracture in older people, a national clinical guidline. Scottish Intercollegiate Guidelines Network 2002.

2. Bhatti N. Hip fracture: eMedicine Web site. http://www.emedicine.com/sports/topic48.htm. Updated December 9, 2005.

3. Freeman C, Todd C, Camilleri-Ferrante C, et al. Quality improvement for patients with hip fracture: experience from a multi-site audit. Qual Saf Health Care 2002;11:239-45.

4. Vondracek S, Hansen L. Current approaches to the management of osteoporosis in men. Am J Health Syst Pharm 2004;61:1801-11.
5. Rosell P, Parker M. Functional outcome after hip fracture. A 1-year prospective outcome study of 275 patients. Injury 2003;34:529-32.

6. Laxton C, Freeman C, Todd C, et al. Morbidity at 3 months after hip fracture: data from the East Anglian audit. Health Trends 1997;29:55-60.

7. Schrader S, Blue R, Horner A. Better Bones Buddies: an osteoporosis prevention program. J Sch Nurs 2005;21:106-14.

8. Homberg A, Johnell O, Nilsson P, et al. Risk factors for hip fractures in a middle-aged population: a study of 33,000 men and women. Osteoporos Int 2005;16:2185-94.

9. Shilbayeh S. Prevalence of osteoporosis and its reproductive risk factors among Jordanian women: a crosssectional study. Osteoporos Int 2003;14:92940.

10. Branco J, Tavares V. Epidemiology of osteoporosis in Portugal. Bone 2001;29:299.

11. Holick MF. Vitamin D Deficiency. N Engl J Med 2007;357:266-81.

12. DK Dhanwal D, Sahoo S, Gautam V. Hip fracture patients in India have vitamin-D deficiency and secondary hyperparathyroidism. Osteoporos Int 2013;24:553-57.

13. Harinarayan C, Joshi S. Vitamin-D Status in India - Its Implications and Remedial Measures. J Assoc Physicians India 2009;57:40-8.

14. Diamond T, Levy S, Smith A, Day P. High bone turnover in Muslim women vitamin deficiency. Med J Aust 2002;177:139-41.

15. Paul T, Selvan S, Asha S, et al. Hypovitaminosis D and Other Risk Factors of Femoral Neck Fracture in South Indian Postmenopausal Women: A Pilot Study. J Clin Diagn Res 2015;9:19-22.

16. Fakler J, Grafe A, Dinger J, et al. Perioperative risk factors in patients with a femoral neck fracture influence of 25-hydroxyvitamin D and C-reactive protein on postoperative medical complications and 1-year mortality. BMC Musculoskeletal Disorders 2016:17:51.

17. Gerald F, Combs J. Vitamins: In: Mahan K. Krause's food, nutrition, \& diet therapy. 10, editor. Scott- Stump, Philadelphia. 2000.

18. Gannage Yared M, Chemali R, Yaacoub N, Halaby G. Hypovitaminosis D in a sunny country: relation to lifestyle a bone markers. J Bone Miner Res 2000;9:1856-92.

19. Holik M. Sunlight and vitamin D for bone health and prevention of autoimmune disease, cancers, and cardiovascular disease. Am J Clin Nutr 2004;80:1678-88.

20. Calvo M, Whiting S, Barton C. Vitamin D intake: a global perspective of current status. J Nutr 2005;135:310-16.

21. Kelsey M, Kenny A. The Role of Diet and Nutritional Status in Recovery from Hip Fracture in the Elderly. Nutrition and Aging 2016:5:113-8. 


\section{Vitamin D3 in hip fractures}

Eur J Transl Myol 28 (3): 288-293, 2018

22. Tkatcha L, Rapina C, Rizzolia R, Slosmana D, Nydeggera V, Vaseya $\mathrm{H}$, et al. Benefits of oral protein supplementation in elderly patients with fracture of the proximal femur. J Am Coll Nutr 1992;11:519-25.

23. Trivedi D, Doll R, Khaw K. Effect of four monthly oral vitamin D3 (cholecalciferol) supplementation on fractures and mortality in men and women living in the community: randomised double blind controlled trial. BMJ 2003;326:469.

Submission: February 21, 2018

Acceptance: April 7, 2018 